\title{
PENGEMBANGAN MODEL PEMBELAJARAN BOLAVOLI PADA SISWA SEKOLAH DASAR KELAS ATAS
}

\author{
DEVELOPING VOLLEYBALL LEARNING MODELS \\ FOR STUDENTS OF UPPER CLASS OF ELEMENTARY SCHOOLS
}

\author{
Mikkey Anggara Suganda, Suharjana \\ PPs UNY, Universitas Negeri Yogyakarta \\ mikkey.anggara@yahoo.com, suharjana_fikuny@yahoo.com
}

\begin{abstract}
Abstrak
Penelitian ini bertujuan untuk menghasilkan model pembelajaran bolavoli pada siswa SD kelas atas yang layak digunakan. Model pembelajaran yang dikembangkan diharapkan untuk digunakan guru SD sebagai salah satu bentuk pembelajaran bolavoli yang baik dan efektif. Penelitian pengembangan ini dilakukan dengan mengadaptasi langkah-langkah penelitian pengembangan sebagai berikut: (1) pengumpulan informasi di lapangan, (2) melakukan analisis terhadap informasi yang telah dikumpulkan, (3) mengembangkan produk awal (draf model), (4) validasi ahli dan revisi, (5) uji coba lapangan skala kecil dan revisi, (6) uji coba lapangan skala besar dan revisi, dan (7) pembuatan produk final. Uji coba skala kecil dilakukan terhadap siswa kelas 4 dari SD Ngringin Depok Sleman yang berjumlah 36 siswa. Uji coba skala besar dilakukan terhadap siswa kelas 4 dan 5 dari SD Sarikarya Yogyakarta yang berjumlah 56 anak. Instrumen pengumpulan data yang digunakan yaitu; (1) pedoman wawancara, (2) skala nilai, (3) pedoman observasi model pembelajaran, (4) pedoman observasi keefektifan model pembelajaran. Teknik analisis data yang dilakukan yaitu analisis deskriptif kuantitatif dan analisis deskriptif kualitatif. Hasil penelitian ini yaitu berupa buku panduan model pembelajaran bolavoli pada siswa sekolah dasar kelas atas, yang berisikan empat model pembelajaran, yaitu: (1) pembelajaran teknik dasar passing bawah, (2) pembelajaran teknik dasar passing atas, (3) pembelajaran teknik dasar servis bawah dan (4) pembelajaran teknik dasar servis atas. Dari hasil penilaian para ahli materi, dapat ditarik kesimpulan bahwa model pembelajaran bolavoli yang disusun sangat baik dan efektif, sehingga model pembelajaran layak digunakan untuk pembelajaran bolavoli pada siswa di kelas atas.
\end{abstract}

Kata kunci: Pengembangan, Model Pembelajaran Bolavoli

\begin{abstract}
This research is aimed at producing an adequate and feasible volleyball learning model for students of upper class of elementary school. This volleyball learning model is developed to help elementary teachers conducting excellent and effective volleyball learning. The research and development $(R$ $\& D)$ was carried out by adapting the steps of research development procedure consisting of: (1) collecting information, (2) information analysis, (3) developing initial products (draft model), (4) expert validation and revision, (5) preliminary field test and revision, (6) main field test and revision, and (7) making the final product. The preliminary field test was conducted to 36 students of the fourth grade of Ngringin Elementary School Depok Sleman. The main field test was conducted to 56 students of the fourth and the fifth grade of Sarikarya Elementary School Yogyakarta. Data collection instruments used were (1) questionnaire guidelines, (2) rating scale, (3) observation learning model guidelines and (4) guidelines for observation effectiveness of learning model. The data were analyzed using quantitative and qualitative descriptive analyses. The result of this research is a guide book of volleyball learning model for students of upper class of elementary schools. The book contains four learning models namely: (1) basic techniques of forearm passing learning, (2) basic techniques of overhand passing learning, (3) basic forearm serve learning and (4) basic overhand serve learning. Based on some experts' judgments, it can be concluded that the model of volleyball learning is very well organized and effective. Therefore, the learning model is appropriate to be applied in volleyball learning towards students of upper class of elementary schools.
\end{abstract}

Keywords: Develoving, Volleyball Learning Models 


\section{Pendahuluan}

Pendidikan pada hakekatnya merupakan proses pembangunan bangsa secara keseluruhan dan bertujuan dalam mengembangkan aspek-aspek kehidupan terutama dalam masa reformasi yang serba transsparan seperti sekarang ini. Pendidikan pada dasarnya bertujuan dalam mencerdaskan kehidupan bangsa yang sasarannya adalah upaya meningkatkan kualitas manusia Indonesia. Dalam Undang-Undang Sistem Pendidikan Nasional No. 20 tahun 2003 disebutkan bahwa fungsi dan tujuan pendidikan nasional adalah sebagai berikut.

"Pendidikan Nasional berfungsi mengembangkan kemampuan dan membentuk watak serta peradapan bangsa yang bermartabat dalam rangka mencerdaskan kehidupan bangsa, bertujuan untuk berkembangnya potensi peserta didik agar menjadi manusia yang beriman dan bertakwa kepada Tuhan Yang Maha Esa, berakhlak mulia, sehat, berilmu, cakap, kreatif, mandiri, dan menjadi warga negara yang demokrasi dan bertanggung jawab".

Dalam rangka mewujudkan tujuan pendidikan nasional tersebut pemerintah telah melakukan berbagai upaya seperti memasukkan mata pelajaran pendidikan jasmani olahraga dan kesehatan (Penjasorkes) di dalam kurikulum sekolah. Pendidikan merupakan salah satu faktor yang menentukan terwujudnya masyarakat adil dan makmur, serta meningkatkan kualitas manusia, sebab pendidikan diselenggarakan secara demokratis dan berkeadilan serta tidak diskriminatif dengan menjujung tinggi hak asasi manusia, nilai keagamaan, nilai kultural, dan kemajemukan bangsa.

Untuk mewujudkan tujuan pendidikan, maka pelaksanaan pendidikan amat dituntut tanggung jawabnya. Dalam perkembangan kehidupan dewasa ini, tugas guru tampaknya semakin hari semakin berat. Guru selalu dituntut untuk mampu melaksanakan proses pembelajaran sesuai dengan bidang keahliannya sehingga dapat meningkatkan martabat guru. Salah satu permasalahan pokok dunia pendidikan adalah pengajaran. Kegiatan pengajaran akan melibatkan berbagai komponen antara lain guru, peserta didik, dan faktor pendukung lainnya. Bila salah satu komponen tidak berfungsi dengan baik, maka kegiatan pengajaran akan terganggu sehingga pencapain tujuan pendidikan tidak akan tercapai.
Guru sebagai salah satu komponen yang bertanggung jawab atas pencapaian pendidikan, keberadaan guru di sekolah sangat menentukan. Guru yang profesional harus mampu melibatkan anak didiknya secara fisik, mental dan emosional dalam pembelajaran. Pembelajaran bertujuan mengembangkan potensi siswa agar dapat tercapainya tujuan yang di harapkan.

Pembelajaran Penjas di sekolah khususnya di sekolah dasar saat ini sudah menjadi perhatian banyak kalangan. Namun yang menjadi kendala dalam pembelajaran Penjas di sekolah-sekolah adalah masih minimnya pengetahuan guru Penjas dalam menerapkan model dan metode yang tepat dalam proses belajar mengajar pembelajaran di sekolah dasar. Hal ini disebabkan kurangnya pengetahuan dan keterbatasan referensi atau sumber bacaan tentang bagaimana guru-guru Penjas mengajarkan model dan metode pembelajaran yang tepat, guna mendukung tercapainya hasil belajar yang diinginkan.

Sanjaya (2010, p.1) mengemukakan adanya masalah dalam dunia pendidikan seperti dinyatakan bahwa salah satu masalah yang dihadapi dunia pendidikan adalah lemahnya proses pembelajaran. Dalam proses pembelajaran, peserta didik kurang didorong untuk mengembangkan kemampuan berfikir. Proses pembelajaran di dalam kelas diarahkan kepada kemampuan peserta didik untuk menghafal informasi, otak peserta didik dipaksa untuk mengingat dan menimbun berbagai informasi tanpa dituntut untuk memahami informasi yang diingatnya untuk menghubungkannya dengan kehidupan sehari-hari. Akibatnya ketika peserta didik lulus dari sekolah, peserta didik pintar secara teoritis tetapi peserta didik miskin aplikasi.

Hal ini juga sesuai dengan yang dikemukakan oleh Hamalik (2009, p.1) bahwa kedudukan dan fungsi guru cenderung lebih dominan sehingga keterikatan guru dalam strategi itu tampak masih terlalu besar, sedangkan keaktifan peserta didik masih terlalu kecil kadarnya. Gejala ini sekaligus menggambarkan bahwa penggunaan strategi masih terbatas pada satu atau dua metode saja, belum meluas dan mencakup penggunaan metode secara luas dan banyak variasinya. Implikasi keadaan ini mengakibatkan hasil belajar peserta didik belum mencapai taraf optimal.

Berdasarkan pernyataan Hamalik di atas menunjukkan bahwa proses pembelajaran, termasuk pembelajaran Penjas di Indonesia masih lemah dan lebih cenderung disampaikan de- 
ngan sebatas memberi informasi saja. Pengembangan berfikir dalam proses pembelajaran masih kurang, sehingga sulit tercapainya tujuan yang diinginkan.

Peranan guru khususnya guru Penjas yang baik, akan terwujud apabila guru memiliki inisiatif, kreatifitas, inovasi, dan dapat membuat model pembelajaran yang menyenangkan peserta didik. Sesuai dangan tingkat perkembangan peserta didiknya, sesuai dengan pembelajaran yang menyenangkan. Guru harus mampu menyajikan program pembelajaran dengan model dan metode yang menarik dan sesuai bagi peserta didik. Peserta didik akan merasa senang dalam proses belajarnya jika seorang guru menggunakan alat-alat atau media tersebut dalam wujud yang sederhana.

Ali (2008, p.1) menyatakan inti dari pada proses pendidikan secara formal adalah mengajar, sedangkan inti proses pengajaran adalah peserta didik belajar. Oleh karena itu mengajar tidak dapat dipisahkan dari belajar, sehingga dalam peristilahan mengenal ungkapan proses belajar mengajar yang disebut PBM.

Menganalisis proses belajar mengajar pada intinya tertumpu pada suatu persoalan, yaitu bagaimana guru memberi kemungkinan peserta didik agar terjadi proses belajar yang efektif atau dapat mencapai hasil sesuai dengan tujuan. Persoalan ini membawa implikasi sebagai berikut: (1) guru harus mempunyai pengetahuan tentang mengajar dan dasar-dasar teori belajar, (2) guru harus dapat mengembangkan sistem pengajaran, (3) guru harus mampu melakukan proses belajar mengajar yang efektif, (4) guru harus mampu melakukan penilaian hasil belajar sebagai dasar umpan balik bagi seluruh proses yang ditempuh (Jumesam, 2010, p.4).

Menyadari arti pentingnya pembelajaran bola besar yakni materi bolavoli dalam pendidikan jasmani untuk anak sekolah dasar, khususnya kelas atas maka peneliti melakukan kajian awal terhadapan muatan Kurikulum Tingkat Satuan Pendidikan (KTSP) 2006 dan peneliti melakukan observasi di lapangan di beberapa sekolah dasar untuk mengungkap lebih lanjut masalah yang ada, sehingga peneliti dapat mencari solusinya dengan menganalisis kebutuhan di lapangan. Oleh karena itu, dilakukan investigasi lebih mendalam terhadap pelaksanaan pembelajaran bolavoli dalam pendidikan jasmani di sekolah dasar, untuk mengetahui kondisi nyata di lapangan. Selain itu peneliti juga ingin mengetahui apakah terdapat permasalahan yang dihadapi guru Penjas SD terkait dengan pelak- sanaan pembelajaran bolavoli di sekolah. Penyelidikan dilakukan dengan melakukan observasi dan wawancara yang dilakukan terhadap beberapa guru Penjas SD yang ada di beberapa sekolah yaitu: SD Negeri Samirono, SD Negeri Puren, SDIT Al Farizi 2, SD Negeri Sarikarya dan SD Negeri Ngringin Depok Sleman Yogyakarta, terungkap bahwa terdapat permasalahan-permasalahan yang dihadapi guru Penjas SD terkait dengan pembelajaran bolavoli sebagai berikut.

Masalah pertama yang dihadapi para guru Penjas SD dalam pelaksanaan pebelajaran bolavoli yaitu tentang sarana dan prasarana pembelajaran Penjas di sekolah dasar, masih banyak sekolah dasar yang belum lengkap/tidak lengkap alat-alat pembelajaran, sehingga guru Penjas dalam hal ini memberikan materi pembelajaran yang kurang bervariasi, kenyataannya seringkali guru mengajar dengan monoton, sehingga siswa akan cepat bosan dan siswa tidak aktif dalam proses belajar mengajar. Hal ini juga dikemukakan oleh seorang guru Penjas Sekolah Dasar Negeri Puren, Yuli Trianto menyatakan "Fasilitas/lapangan dan peralatan olahraga yang dimiliki sekolah dasar tempat mengajar masih sangat kurang, terutama lapangan tempat anak-anak bermain dan sebagai prasarana penting dalam pembelajaran Penjas, hal ini menimbulkan terganggunya proses belajar mengajar serta dalam memberikan materi pelajaran tidak berjalan dengan apa yang diharapkan".

Masalah kedua yang dihadapi guru Penjas dalam pelaksanaan pembelajaran bolavoli yaitu kurangnya kreativitas guru Penjas dalam menyusun model pembelajaran bolavoli yang variasi dan menarik sehingga anak tidak bosan. Kurangnya variasi dalam model pembelajaran berpengaruh terhadap cara guru mengajar di lapangan yang masih bersifat konvensional dan minim pembaharuan di dalam pembelajaran. Seperti pembelajaran bolavoli dalam pendidikan jasmani di sekolah seorang guru memberi materi pembelajaran praktik bolavoli yang sama pada setiap semester tanpa adanya pengembangan variasi gerak atau modifikasi sehingga bersifat monoton, serta masih adanya persepsi guru bahwa anak sekolah dasar kelas atas tidak perlu berlama-lama melakukan praktik dalam pembelajaran Penjas karena anak akan mengalami kelelahan.

Dari berbagai bentuk permasalahan yang banyak terjadi di sekolah-sekolah dan setiap sekolah mempunyai masalah yang berbeda-beda, dalam hal ini peneliti berencana me- 
ngembangkan suatu bentuk pembelajaran yang hanya terfokus pada materi bolavoli. Keadaan di lapangan ini menunjukkan materi pelajaran Penjas belum berjalan sesuai keinginan dan harapan disebabkan kerena sarana dan prasarana di sekolah dasar yang masih kurang memadai, serta kinerja guru harus benar-benar efektiv dan efisien agar apa yang diharapkan dapat dicapai.

Terkait dengan hal itu, maka sangat dibutuhkan studi yang matang dan mendalam, mengenai model dan metode yang tepat untuk pembelajaran Penjas khususnya materi bolavoli. Dengan demikian melalui penelitian ini diharapkan akan didapat solusi atau jawaban tentang model dan metode pembelajaran yang tepat untuk mengajarkan pembelajaran pada peserta didik sekolah dasar, peneliti mencoba menerapkan model dan metode ini di SD Negeri Ngringin Depok Sleman DI Yogyakarta.

Metode yang dikembangkan dalam penelitian ini adalah dengan model pembelajaran bolavoli pada siswa sekolah dasar kelas atas, diharapkan akan mendapat kemudahan dalam penguasaan keterampilan dengan menerapkan model pembelajaran dengan tujuan peserta didik akan lebih tertarik untuk melakukan sesuatu gerakan yang menjadi materi pembelajaran, sehingga hasil belajarnya akan meningkat, dan lebih penting adalah peserta didik akan merasa senang dan tertarik untuk melakukan permainan bolavoli.

\section{Waktu dan Tempat Penelitian}

Penelitian dan pengembangan ini dilakukan mulai bulan Desember sampai bulan Mei. Studi pendahuluan dilakukan di SD Negeri Puren, SD Negeri Samirono, SD Negeri IT AlFarizi 2, SD Negeri Ngringin, dan SD Negeri Sarikarya, Depok Sleman Yogyakarta. Tempat Uji coba lapangan skala kecil dilakukan di SD Negeri Ngringin Depok Sleman Yogyakarta, sementara uji coba lapangan skala besar dilakukan di sekolah SD Negeri Sarikarya Depok Sleman Yogyakarta.

\section{Target/Subjek Penelitian}

Subjek coba dalam penelitian pengembangan ini adalah siswa sekolah dasar kelas atas. Uji coba lapangan skala kecil dilakukan terhadap siswa sekolah dasar kelas atas (kelas IV) SD Negeri Ngringin Depok Sleman Yogyakarta yang berjumlah 36 anak. Sementara uji coba lapangan skala besar dilakukan terhadap siswa sekolah dasar kelas atas (kelas IV dan V)
SD Negeri Sarikarya Depok Sleman Yogyakarta yang berjumlah 56 anak.

\section{Prosedur Penelitian dan Pengembangan}

Prosedur pengembangan dalam penelitian ini sejalan dengan langkah-langkah penelitian pengembangan menurut Borg \& Gall (1983, p.775) yang terdiri dari 10 langkah, yaitu: (1) potensi dan masalah, (2) pengumpulan data, (3) desain produk, (4) validasi desain, (5) revisi desain, (6) ujicoba produk, (7) revisi produk, (8) ujicoba pemakaian, (9) revisi produk, dan (10) produksi masal. Langkah-langkah tersebut di atas diadaptasi menjadi 7 (tujuh) prosedur penelitian pengembangan berikut ini:

\section{Pengumpulan Informasi di Lapangan}

Peneliti melakukan kajian awal mengenai muatan kurikulum pendidikan jasmani di $\mathrm{SD}$, dan berasumsi bahwa terdapat permasalahan yang dihadapi guru Penjas SD dalam pelaksanaan pembelajaran bolavoli di lapangan. Proses selanjutnya, peneliti melakukan observasi atau prasurvei lapangan (studi pendahuluan) di beberapa sekolah dasar untuk memperoleh informasi lebih lanjut kondisi dan permasalahan yang dihadapi guru Penjas SD tentang pelaksanaan pembelajaran bolavoli di sekolah. Peneliti melakukan wawancara langsung dengan para guru Penjas SD di lapangan. Wawancara dilakukan terhadap beberapa guru Penjas SD yang ada di beberapa sekolah yaitu: SD Negeri Samirono, SD Negeri Puren, SD IT Alfarizi 2, SD Negeri Sarikarya, SD Negeri Ngringin Depok Sleman Yogyakarta.

Berdasarkan hasil observasi dan wawancara (studi pendahuluan) yang dilakukan terhadap beberapa guru Penjas SD yang ada di beberapa sekolah, maka terungkap permasalahan-permasalahan yang dihadapi oleh guru penjas SD terkait dengan pembelajaran bolavoli sebagai berikut: (1) Kurangnya pengalaman dan kreativitas yang diajarkan oleh guru Penjas dalam menyusun model pembelajaran bolavoli, sehingga berpengaruh terhadap proses pembelajaran yang masih bersifat konvensional. (2) Kondisi sarana dan prasarana yang kurang memadai di sekolah dasar. (3) Kurangnya kreaktivitas guru Penjas dalam menyiapkan sarana pembelajaran (modifikasi peralatan olahraga) yang sesuai dengan kandungan kurikulum secara mudah dan praktis guna mengatasi keterbatasan ketersediaan sarana dan prasarana. 


\section{Analisis Terhadap Informasi yang telah Dikumpulkan}

Analisis dilakukan terhadap data hasil studi pustaka dan wawancara. Analisis terhadap hasil studi pustaka digunakan untuk pemantapan dalam memfokuskan masalah yang dikaji. Sementara analisis terhadap hasil wawancara dilakukan untuk mengetahui kebenaran asumsi peneliti dari kondisi nyata di lapangan mengenai permasalahan yang ada. Selanjutnya, disimpulkan mengenai permasalahan-permasalahan yang dihadapi guru Penjas SD dalam pembelajaran bolavoli di lapangan.

\section{Mengembangkan Produk Awal}

Setelah proses analisis, peneliti mulai mengembangkan suatu produk awal (draf awal) model pembelajaran bolavoli. Produk ini masih berupa produk awal dan dalam pengembangannya dilakukan hal-hal sebagai berikut: (a) Menganalisis muatan materi pembelajaran bolavoli dan Standar Kompetensi (KD)/Kompetensi Dasar (KD) yang ingin dicapai dalam kurikulum Penjas SD, agar produk yang dikembangkan tidak menyimpang dari panduan kurikulum yang ada, (b) Menganalisis karakteristik siswa sekolah dasar kelas atas, (c) Menganalisis tujuan pengembangan model pembelajaran bolavoli dengan pendekatan bermain, (d) Mengembangkan model pembelajaran bolavoli dengan pendekatan bermain yang sesuai dengan kurikulum Pendidikan jasmani sekolah dasar.

\section{Validasi Ahli dan Revisi}

Sebelum dilakukan uji coba skala kecil terhadap produk awal, produk harus mendapat validasi dari para ahli materi, yaitu: (1) pakar pembelajaran pendidikan jasmani, (2) pakar pembelajaran bolavoli, dan (3) pakar pendidikan jasmani (guru Penjas SD). Tujuan validasi ahli adalah untuk mendapatkan pengesahan serta masukan terhadap draf produk awal yang dikembangkan, sehingga produk layak untuk diujicobakan di lapangan.

Pada proses validasi, para ahli materi menilai dan memberi masukan terhadap produk awal. Berdasarkan hal tersebut, dilakukan revisi terhadap produk awal. Proses revisi ini terus dilakukan sampai produk awal mencapai batas nilai tertentu yang telah ditetapkan, yang menunjukkan bahwa produk awal tersebut valid dan layak diujicobakan.

\section{Uji Coba Lapangan Skala Kecil dan Revisi}

Uji coba lapangan skala kecil dilakukan dan didokumentasikan dalam bentuk Video Compact Disc (VCD), yang kemudian diobservasi oleh para ahli materi. Penilaian Observasi oleh para ahli dilakukan terhadap substansi model dan keefektifan model pembelajaran bolavoli dikembangkan, dengan menggunakan pedoman observasi yang disusun oleh peneliti. Masukan yang diterima dari para pakar dan guru Penjas SD ditindaklanjuti dengan melakukan revisi produk. Selain itu, masukan dari guru Penjas pelaku uji coba juga dipertimbangkan sebagai bahan untuk merevisi produk.

\section{Uji Coba Lapangan Skala Besar dan Revisi}

Proses yang dilakukan pada tahap uji coba lapangan skala besar serupa dengan proses yang dilakukan pada tahap uji coba skala kecil. Hal yang membedakan terletak pada jumlah subjek uji coba skala besar yang lebih banyak daripada uji coba skala kecil. Dalam hal ini, subjek uji coba yang sudah mengikuti uji coba skala kecil tidak turut serta dalam uji coba skala besar. Proses revisi produk dilakukan setelah mendapat masukan dari para ahli materi untuk menghasilkan produk final. Masukan dari guru Penjas SD pelaku uji coba skala besar juga dipertimbangkan sebagai bahan untuk merevisi produk.

\section{Pembuatan Produk Final.}

Setelah melalui berbagai proses ujicoba lapangan dan revisi, maka dilakukan penyusunan dan pembuatan produk akhir (produk final) berupa buku panduan model pembelajaran bolavoli untuk anak sekolah dasar kelas atas yang berisikan berisikan enam permainan (masingmasing meliputi beberapa bentuk variasi gerak) yaitu: (1) pembelajaran teknik dasar passing bawah, (2) pembelajaran teknik dasar passing atas, (3) pembelajaran teknik dasar servis bawah dan (4) pembelajaran teknik dasar servis atas.

\section{Data, Intrumen, dan Teknik Pengumpulan Data}

Jenis data yang diperoleh dalam penelitian pengembangan ini berupa data kualitatif dan data kuantitatif. Data kualitatif berasal dari: (1) data masukan dari para ahli materi dan guru pelaku uji coba, dan (2) hasil wawancara dengan guru Penjas SD. Data kuantitatif diperoleh dari: (1) data hasil penilaian skala nilai dari para 
ahli materi, (2) data hasil penilaian observasi model dari para ahli materi, (3) data hasil penilaian observasi keefektifan model dari para ahli, dan (4) data kuesioner siswa. Data-data tersebut digunakan untuk mengevaluasi model pembelajaran bolavoli untuk anak sekolah dasar kelas atas.

Instrumen yang digunakan untuk mengumpulkan data dalam penelitian dan pengembangan ini terdiri dari: (1) pedoman wawancara, (2) angket skala nilai (Rating scale), (3) pedoman observasi model, (4) pedoman observasi keefektifan model, dan (5) kuesioner untuk siswa.

Teknik pengumpulan data pertama yang digunakan yaitu teknik komunikasi langsung dengan menggunakan instrumen wawancara sebagai alat pengumpul data. Subana (Riduwan, 2007, p.29) menyatakan bahwa wawancara merupakan alat pengumpul data yang digunakan untuk memperoleh informasi langsung dari sumbernya. Wawancara digunakan untuk mengetahui hal-hal dari responden, ada beberapa faktor yang akan mempengaruhi arus informasi dalam wawancara yaitu: pewawancara, responden, pedoman wawancara, dan situasi wawancara. Pewawancara adalah petugas pengumpul informasi yang diharapkan dapat menyampaikan pertanyaan dengan jelas. Responden adalah pemberi informasi yang diharapkan dapat menjawab semua pertanyaan dengan jelas dan lengkap. Pedoman wawancara berisi tentang uraian penelitian yang biasanya dituangkan dalam bentuk pertanyaan. Situasi wawancara berhubungan dengan waktu dan tempat wawancara (Riduwan, 2007, p.29).

Wawancara yang dilakukan yaitu wawancara bebas terpimpin, di mana pedoman wawancara digunakan sebagai pegangan pewawancara dalam mewawancarai responden. Pedoman wawancara tidak berbentuk seperangkat pertanyaan, namun hanya berbentuk butir-butir pertanyaan yang perlu disampaikan, yang disusun berdasarkan masalah, sub masalah dan variabel penelitian. Butir-butir tersebut merupakan pegangan agar data yang dikumpulkan tidak menyimpang dari masalah yang ingin digali. Pewawancara membawa pedoman yang hanya merupakan garis besar tentang hal-hal yang ingin ditanyakan (Riduwan, 2007, p.30). Pewawancara menyusun sendiri kalimat pertanyaan tentang butir-butir tersebut yang redaksionalnya kadang berbeda, tetapi isinya sama setiap menyampaikan pertanyaan pada setiap responden.
Instrumen pengumpul data kedua yang digunakan yaitu skala nilai. Skala nilai digunakan untuk menilai kelayakan model pembelajaran bolavoli yang dikembangkan sebelum pelaksanaan uji coba skala kecil, setelah para ahli menilai bahwa pembelajaran bolavoli sudah sesuai dengan unsur-unsur dalam skala nilai, model pembelajaran bolavoli baru dapat diuji cobakan dalam uji coba skala kecil.

Di dalam skala nilai, variabel atau tujuan penelitian diklasifikasikan secara rinci menjadi gejala-gejala dengan unsur-unsurnya. Klasifikasi tersebut disusun ke bawah, sedangkan ke samping dicantumkan kategori sesuai dengan maksud/tujuan penelitian, antara lain berupa urutan kualitas data yang dikumpulkan. Kategori yang dimaksud dalam skala penilaian adalah kategori berskala empat, yaitu sangat sesuai, sesuai, cukup sesuai dan tidak sesuai. Cara penggunaan skala nilai yaitu, bilamana muncul gejala atau unsur-unsur seperti yang terdapat dalam klasifikasi data, para pakar dan guru memberikan tanda cek $(\sqrt{ })$ pada kolom kategori. Apabila gejala atau unsur-unsur seperti yang terdapat dalam klasifikasi data dinyatakan sangat sesuai maka nilainya empat (4), apabila dinyatakan sesuai maka nilainya tiga (3), apabila dinyatakan cukup sesuai nilainya dua (2), serta apabila dinyatakan tidak sesuai nilainya satu (1).

Teknik pengumpulan data ketiga yang digunakan yaitu teknik observasi tidak langsung dengan instrumen observasi berupa daftar cek (check list) dan peralatan mekanik. Teknik observasi merupakan cara mengumpulkan data yang dilakukan melalui pengamatan, dengan pengamatan terdapat kemungkinan untuk mencatat hal-hal, perilaku, pertumbuhan, dan sebagainya sewaktu kejadian tersebut berlangsung (Nazir, 2011, p.175).

Dalam instrumen observasi disediakan daftar cek untuk memudahkan pengamat mengamati gejala-gejala yang akan diamati. Instrumen observasi dibuat supaya peneliti mengetahui aspek apa yang diamati releven dengan masalah serta tujuan peneliti. Ada dua alat yang dapat membantu pengamatan antara lain yaitu sistem kategori dan menggunakan rating scale. Alat yang dipakai dalam membantu instrumen observasi yaitu menggunakan ratting scale. Ratting scale adalah sebuah instrumen yang mewajibkan pengamat untuk menetapkan subjek pada kategori dengan memberikan nomor atau angka pada kategori-kategori tersebut (Nazir, 2011, pp.181-185). 
Cara mencatat observasi tidak mempunyai standar tertentu, yang paling penting adalah fenomena dapat dicatat dan perilaku dapat diketahui dengan jelas. Tugas pencatat (pengamat) yaitu memberi tanda pada kategori di mana perilaku tersebut cocok ditempatkan di SD, alat yang digunakan untuk memberi tanda bisa dengan pensil maupun bolpoin. Pencatat (pengamat) memberikan tanda cek berupa tanda silang, coretan berbentuk huruf $(\sqrt{ })$ atau dilingkari dan bentuk lain yang ditetapkan secara pasti dan digunakan secara seragam dan konsekuen selama pengamatan dilakukan (Nazir, 2011, p.186).

Teknik pengumpulan data keempat yaitu lembar kuesioner untuk siswa. Kuesioner siswa digunakan untuk mengetahui respon dari peserta didik terhadap produk model yang dikembangkan. Kuesioner siswa berisikan sejumlah pertanyaan dengan alternatif jawaban "Ya" dan "Tidak". Siswa mengisi kuesioner dengan membubuhkan tanda cek $(\sqrt{ })$ pada atlernatif Jawaban sesuai dengan apa yang dirasakan selama mengikuti proses pembelajaran bolavoli dengan model yang dikembangkan.

Teknik Analisis Data

Teknik analisis data yang dilakukan dalam penelitian ini yaitu analisis deskriptif kuantitatif dan analisis deskriptif kualitatif. Analisis deskriptif kuantitatif dilakukan untuk menganalisis data-data berikut: (1) data skala nilai hasil penilaian para ahli materi terhadap draf model pembelajaran bolavoli sebelum pelaksanaan uji coba di lapangan, (2) data hasil observasi para ahli materi terhadap model pembelajaran bolavoli, dan (3) data hasil observasi para ahli materi terhadap keefektifan pembelajaran bolavoli. Sementara analisis deskriptif kualitatif dilakukan terhadap: (1) data hasil wawancara dengan guru SD saat studi pendahuluan, (2) data kekurangan dan masukan terhadap model pembelajaran bolavoli baik sebelum uji coba maupun setelah uji coba di lapangan.

Draf awal pembelajaran bolavoli dianggap layak untuk diujicobakan dalam skala kecil apabila para ahli materi telah memberi validasi dan menyatakan bahwa semua item klasifikasi dalam skala nilai dinilai "sesuai/sangat sesuai" dengan cara memberi tanda centang $(\sqrt{ })$ pada kolom sesuai/sangat sesuai. Dalam hal ini terdapat empat jenis nilai, yaitu hasil penilaian "sangat sesuai" mendapat nilai empat (4) "sesuai" mendapat nilai tiga (3) "cukup sesuai" mendapat nilai dua (2) dan hasil penilaian "tidak sesu- ai" mendapat nilai satu (1). Jika terdapat ahli materi yang berpendapat bahwa item klasifikasi tidak sesuai (nilai satu), maka dilakukan pengkajian ulang terhadap model pembelajaran bolavoli yang dapat ditindaklanjuti dengan proses revisi.

Untuk data hasil observasi para ahli materi terhadap model pembelajaran bolavoli, keefektifan model pembelajaran bolavoli, dan guru pelaku uji coba terdapat dua jenis nilai. Terlebih dahulu ditentukan kriteria nilai dan batas-batasnya, yang akan dipaparkan pada Tabel 1.

Tabel 1. Pedoman Konversi Nilai

\begin{tabular}{cc}
\hline Formula & Kategori \\
\hline $\mathrm{X}<(\mu-1,0 \sigma)$ & Kurang Baik/Efektif \\
$(\mu-1,0 \sigma) \leq X<(\mu+1,0 \sigma)$ & Cukup Baik/Efektif \\
$(\mu+1,0 \sigma) \leq X$ & Baik/Efektif \\
\hline
\end{tabular}

Sumber: Azwar (2005, p.109)

\section{Hasil Penelitian dan Pembahasan}

\section{Data Validasi Ahli}

Dari hasil penilaian skala nilai (Rating scale) yang diberikan pakar/ahli materi terhadap revisi draf awal model sebelum diujicobakan di lapangan, para ahli materi: (1) ahli pembelajaran pendidikan jasmani, (2) ahli pembelajaran bolavoli, dan (3) ahli guru pendidikan jasmani sekolah dasar, berpendapat bahwa model pembelajaran bolavoli yang terdiri dari 4 model, yaitu (1) pembelajaran teknik dasar passing bawah, (2) pembelajaran teknik dasar passing atas, (3) pembelajaran teknik dasar servis bawah dan (4) pembelajaran teknik dasar servis atas, yang dikembangkan dinilai telah "sesuai" dengan item-item klasifikasi dalam penilaian skala nilai sehingga dinyatakan layak untuk diujicobakan di lapangan.

\section{Data Uji Coba Lapangan Skala Kecil}

Setelah mendapatkan validasi para ahli materi terhadap draf awal model pembelajaran bolavoli, peneliti melakukan uji coba lapangan skala kecil di SD Negeri Samirono Depok Sleman Yogyakarta. Dari pelaksanaan uji coba skala kecil, didapatkan data dari ahli materi (bidang ahli pembelajaran pendidikan jasmani, bidang ahli pembelajaran bolavoli, dan guru pendidikan jasmani SD) meliputi: (1) data hasil observasi model pembelajaran bolavoli, (2) data hasil observasi keefektifan model pembelajaran bolavoli, (3) data masukan terhadap model pembelajaran bolavoli, dan data respon dari 
siswa terhadap model pembelajaran bolavoli. Data-data tersebut dipaparkan berikut ini.

\section{Data Observasi Model}

Dari penilaian ahli materi terhadap observasi model pembelajaran bolavoli pada uji coba skala kecil, para ahli materi menilai bahwa model pembelajaran bolavoli yang terdiri dari 4 model, yaitu: (a) pembelajaran teknik dasar passing bawah, (b) pembelajaran teknik dasar passing atas, (c) pembelajaran teknik dasar servis bawah, dan (d) pembelajaran teknik dasar servis atas, menunjukkan: tidak ada subjek $(0 \%)$ yang memandang kurang, tidak ada subjek $(0 \%)$ yang memandang cukup, dan 3 responden $(100,00 \%)$ memandang baik. Total nilai para ahli semuanya terletak pada interval $30 \leq$ $\mathrm{X}$, maka pandangan para ahli materi terhadap hasil observasi model pembelajaran bolavoli untuk anak sekolah dasar kelas atas memandang baik.

\section{Data Observasi Keefektifan Model}

Dari penilaian ahli materi terhadap observasi keefektifan model pembelajaran bolavoli pada uji coba skala kecil, para ahli materi menilai bahwa model pembelajaran bolavoli yang terdiri dari 4 model, yaitu (a) pembelajaran teknik dasar passing bawah, (b) pembelajaran teknik dasar passing atas, (c) pembelajaran teknik dasar servis bawah dan (d) pembelajaran teknik dasar servis atas, menunjukkan: tidak ada subjek (0\%) yang memandang kurang baik/ efektif, tidak ada subjek $(0 \%)$ yang memandang cukup baik/efektif, dan 3 responden atau ahli materi $(100,00 \%)$ memandang baik/efektif. Total nilai para ahli semuanya terletak pada interval $33 \leq \mathrm{X}$, maka pandangan para ahli materi terhadap hasil observasi keefektifan model pembelajaran bolavoli pada anak sekolah dasar kelas atas yang dikembangkan termasuk dalam kategori efektif.

\section{Data Kekurangan dan Masukan Ahli Materi}

Meskipun model sudah memenuhi item-item observasi, namun terdapat beberapa masukan dari para ahli materi yaitu (1) Buatlah garis lintasan pada setiap kelompok siswa pada saat melakukan pembelajaran bolavoli, (2) Disiplin peraturan pada siswa, (3) Siswa jangan menunggu tertalu lama, perbanyak barisan dan bola, (4) Pada model passing atas dengan variasi passing atas segitiga ke belakang, usahakan siswa melakukan passing atas dengan cara menolak bukan melempar, (5) Tambahkan sistemati- ka pembelajaran, dan (6) Buatlah RPP serta format penilaian untuk siswa menyikapi masukan dari para ahli materi terhadap model yang dikembangkan, peneliti melakukan perbaikan untuk penyempurnaan produk lebih lanjut sebelum dilakukan uji coba skala besar.

\section{Data Kuesioner Siswa}

Data kuesioner untuk siswa menunjukkan bahwa respon dari peserta didik yang menjadi sampel pada uji coba skala kecil, secara umum memberikan respon yang positif terhadap model pembelajaran bolavoli. Peserta didik merasa senang melakukan permainan yang diajarkan dan ingin melakukannya kembali di luar jam sekolah atau di rumah.

\section{Data Uji Coba Lapangan Skala Besar}

Setelah dilakukan uji coba skala kecil dan proses revisi terhadap draf model pembelajaran bolavoli berdasarkan hasil observasi dan masukan-masukan dari ahli materi. Langkah selanjutnya peneliti melakukan uji coba lapangan skala besar di SD Negeri Sarikarya Sleman Yogyakarta. Dari pelaksanaan uji coba skala besar, didapatkan data dari ahli materi (bidang ahli pembelajaran pendidikan jasmani, bidang ahli pembelajaran bolavoli, dan guru pendidikan jasmani SD) meliputi: (1) data hasil observasi model pembelajaran bolavoli, (2) data hasil observasi keefektifan model pembelajaran bolavoli, (3) data masukan terhadap model pembelajaran bolavoli, dan data respon dari siswa terhadap model pembelajaran bolavoli. Data-data tersebut dipaparkan berikut ini.

\section{Data Observasi Model}

Dari penilaian ahli materi terhadap observasi model pembelajaran bolavoli pada uji coba skala kecil, para ahli materi menilai bahwa model pembelajaran yang terdiri dari 4 model, yaitu: (a) pembelajaran teknik dasar passing bawah, (b) pembelajaran teknik dasar passing atas, (c) pembelajaran teknik dasar servis bawah dan (d) pembelajaran teknik dasar servis atas, menunjukkan: tidak ada subjek $(0 \%)$ yang memandang kurang, tidak ada subjek (0\%) yang memandang cukup, dan 3 responden $(100,00 \%)$ memandang baik. Total nilai para ahli semuanya terletak pada interval $30 \leq \mathrm{X}$, maka pandangan para ahli materi terhadap hasil observasi model pembelajaran bolavoli untuk anak sekolah dasar kelas atas memandang baik.

Data Observasi Keefektifan Model 
Dari penilaian ahli materi terhadap observasi keefektifan model pembelajaran bolavoli pada uji coba skala kecil, para ahli materi menilai bahwa model pembelajaran bolavoli yang terdiri dari 4 model, yaitu (a) pembelajaran teknik dasar passing bawah, (b) pembelajaran teknik dasar passing atas, (c) pembelajaran teknik dasar servis bawah dan (d) pembelajaran teknik dasar servis atas, menunjukkan: tidak ada subjek (0\%) yang memandang kurang baik/efektif, tidak ada subjek $(0 \%)$ yang memandang cukup baik/efektif, dan 3 responden atau ahli materi $(100,00 \%)$ memandang baik/ efektif. Total nilai para ahli semuanya terletak pada interval $33 \leq \mathrm{X}$, maka pandangan para ahli materi terhadap hasil observasi keefektifan model pembelajaran bolavoli pada anak sekolah dasar kelas atas yang dikembangkan termasuk dalam kategori efektif.

Data Kekurangan dan Masukan Ahli Materi

Berdasarkan hasil observasi dari ahli materi terhadap pelaksanaan uji coba skala besar model pembelajaran bolavoli, para ahli materi mengangap bahwa model yang dikembangkan sudah baik dan efektif, sehingga tidak ada masukan lagi atau tidak diperlukan revisi.

\section{Data Kuesioner Siswa}

Data kuesioner untuk siswa, menunjukkan bahwa respon dari peserta didik yang menjadi sampel pada uji coba skala besar, secara umum memberikan respon yang positif terhadap model pembelajaran bolavoli. Peserta didik merasa senang melakukan permainan yang diajarkan dan ingin melakukannya kembali di luar jam sekolah atau di rumah. Setelah mendapat penilaian dan masukan, baik dari para ahli materi maupun guru pendidikan jasmani sekolah dasar pelaku uji coba kemudian dilakukan proses-proses revisi terhadap draf model pembelajaran bolavoli yang dikembangkan. Proses revisi terhadap produk model pembelajaran bolavoli ini terdiri dari: (1) revisi draf produk awal, (2) revisi produk uji coba skala kecil, dan (3) revisi produk uji coba skala besar. Akhirnya dihasilkan model pembelajaran bolavoli untuk anak sekolah dasar kelas atas, yang terdiri dari empat model permainan (masing-masing meliputi beberapa bentuk variasi gerak), yaitu: (1) pembelajaran teknik dasar passing bawah, (2) pembelajaran teknik dasar passing atas, (3) pembelajaran teknik dasar servis bawah dan (4) pembelajaran teknik dasar servis atas, yang di- susun dalam bentuk buku panduan dan layak untuk digunakan.

\section{Simpulan dan Saran}

Simpulan

Berdasarkan hasil penelitian, maka dapat diambil kesimpulan bahwa model pembelajaran bolavoli pada siswa sekolah dasar kelas atas yang terdiri dari 4 model permainan, yaitu: (a) pembelajaran teknik passing bawah, (b) pembelajaran teknik passing atas, (c) pembelajaran teknik servis bawah, (d) pembelajaran teknik passing atas. Model pembelajaran bolavoli disesuaikan dengan standar kompetensi dan kompetensi dasar yang termuat dalam kurikulum, disesuaikan dengan pertumbuhan dan perkembangan anak SD, serta disesuaikan dengan tingkat keamanan pelaksanaan kegiatan di sekolah. Model pembelajaran bolavoli yang dibuat, juga layak digunakan untuk pembelajaran bola besar yakni materi bolavoli. Uji kelayakan dilakukan berdasarkan penilaian para ahli materi, penilaian ahli materi menunjukkan bahwa model pembelajaran bolavoli yang disusun layak untuk digunakan sebagai pembelajaran bola besar yakni materi bolavoli pada siswa SD kelas atas.

\section{Saran}

Saran pemanfaatan berdasarkan penelitian pengembangan yaitu agar model pembelajaran bolavoli yang dikembangkan dapat digunakan guru sebagai salah satu bentuk pembelajaran bola besar, untuk dapat mewujudkan hal tersebut, perlu ditingkatkan kemauan dan kesediaan guru untuk senantiasa meningkatkan kualitas pembelajaran dengan berbagai bentuk/model pembelajaran yang dapat meningkatkan minat dan kualitas siswa dalam belajar, meskipun hal tersebut berarti menambah kesibukan guru dalam menyiapkan bahan-bahan pembelajaran.

Diseminasi hasil penelitian ini dapat dilakukan melalui seminar-seminar, dan dalam bentuk pembuatan artikel, atau dapat juga dilakukan melalui penelitian tindakan kelas ataupun eksperimen dengan melibatkan guru SD untuk mengetahui efek nyata dari produk pembelajaran bolavoli.

Untuk pengembangan produk lebih lanjut perlu dilakukan penelitian yang melibatkan subjek coba lebih besar dan cakupan tempat uji coba yang lebih luas. Di sisi lain, dapat juga dilakukan penelitian serupa dengan sasaran subjek siswa SD kelas bawah. 


\section{Daftar Pustaka}

Ali, Muhammad. (2008). Guru dalam proses belajar mengajar. Bandung: PT. Sinar Baru Algensindo

Borg, Walter R. \& Gall. M. D. (1983). Educational research. (an introduction) $4^{\text {th }}$ edition. New York \& London: Longman.

Depdiknas. (2003). Undang-undang republik Indonesia tentang sistem pendidikan. nasional. Jakarta: Cipta.

Hamalik, Oemar. (2006). Proses belajar mengajar. Jakarta: PT. Bumi Aksara.
Jumesam. (2010). Perkembangan model pembelajaran motorik untuk anak sekolah dasar. Tesis magister, tidak diterbitkan. Universitas Negeri Yogyakarta.

Nazir, Moh. (2011). Metode penelitian. Bogor: Ghalia Indonesia.

Riduwan. (2007). Skala pengukuran variabelvariabel penelitian. Bandung: Alfabeta.

Sanjaya, Wina, (2010). Strategi pembelajaran berorientasi standar proses pendidikan. Jakarta: PT. Kencana Prenanda Media Group. 